\title{
ESTIMATION OF WHEAT STRAW AND RAPESEED USEFULNESS FOR WHEAT FERTILISATION IN ARABLE FARMING
}

\author{
Sławomir Stankowski ${ }^{1}$, Bożena Michalska², Janusz Smagacz ${ }^{3}$, \\ Marzena Gibczyńska ${ }^{4}$
}

1 Department of Agronomy, West Pomeranian Technological University in Szczecin, Papieża Pawła VI 3, 71-459 Szczecin, Poland, e-mail: sstankowski@hoga.pl

2 Department of Meteorology and Green Areas Management, West Pomeranian Technological University in Szczecin, Papieża Pawła VI 3, 71-459 Szczecin, Poland, e-mail: bozena.michalska@zut.edu.pl

3 Institute of Soil Science and Plant Cultivation, State Research Institute, Czartoryskich 8, 24-100 Puławy, Poland, e-mail: smagacz@iung.pulawy.pl

4 Department of General and Ecological Chemistry, West Pomeranian Technological University in Szczecin, 71-434 Szczecin, Słowackiego 17, Poland, e-mail: marzena.gibczynska@zut.edu.pl

Received: 2014.11 .02

Accepted: 2015.02 .04

Published: 2015.04.01

\begin{abstract}
The aim of the research was the estimation of wheat and rapeseed straw usefulness for fertilising plants in arable farming. The subject matter of the study was the analysis of the influence of soil fertilisation with wheat and rapeseed straw on the yield and changes in the content of phosphorus, potassium, calcium and magnesium in winter wheat grain cultivars: Finezja and Ludwig. The static field experiment was conducted at Agricultural Experiment Station, Grabów, Institute of Soil Science and Plant Cultivation - State Research Institute $\left(51^{\circ} 21^{\prime} \mathrm{N}, 21^{\circ} 40^{\prime} \mathrm{E}\right)$ in the years $2008-2010$ on Haplic Luvisol. The effect of fertilisation with wheat and rapeseed straw did not have a significant effect on grain yield of winter wheat cultivars 'Finezja' and 'Ludwig'. The introduction of complementary nitrogen fertilisation caused an increase in grain yield of wheat cultivar Ludwig. Organic fertilisation with wheat and rapeseed straw as well as complementary nitrogen fertilisation did not significantly differentiate the content of phosphorus, potassium, calcium and magnesium in winter wheat grain cultivars 'Finezja' and 'Ludwig'.
\end{abstract}

Keywords: 'Finezja' and 'Ludwig' wheat, magnesium, phosphorus, potassium, calcium, soil fertilization.

\section{INTRODUCTION}

Straw is ripe or dry stalk of cereal plants as well as of legumes, flax or rapeseed. The regulation of the Minister of Environment on R10 recovery operation [Dz.U. 2011, 86, 476] includes categorises of straw, as a kind of waste product, as plant-tissue waste with a code: 020103 . The appendix to the Regulation specifies the conditions of R10 recovery operation and classifies waste for distribution on the surface of soil in order to fertilise or ameliorate soil. The regulation provides for the condition that waste is used in soil in which the admissible concentration val- ues of substances, specified in the Regulation of the Minister of Environment, dated 9 September 2002 on soil quality standards and land quality standards, are not exceeded [Dz.U. 2002, 165, 1359]. However, taking into consideration the decreasing content of organic matter in soils in Poland, the most favourable solution is recirculation of organic matter and nutrients, contained in crop residue, in arable fields [Ministry of agriculture and rural development Warsaw 2010]. Straw is a basic organic fertiliser in stock-free farming. Straw of cereals can be a good organic fertiliser under the condition that it is milled into particles sized most preferably less than $10 \mathrm{~cm}$ 
and ploughed immediately after grain gathering. After ploughing of straw the nutrients contained therein circulate in soil and additionally constitute a good humus creating material. The nutrients contribute to greater utilisation and efficacy of mineral fertilisers. Wheat straw is characterised by the content of phosphorus, potassium calcium and magnesium: $1.3,6.8,5.6$ and $1,3 \mathrm{~g} \cdot \mathrm{kg}^{-1}$ d.m. respectively [Buraczyńska and Ceglarek 2011a]. Rapeseed straw which contains particularly high amount of calcium and potassium as well as other components is valued more than that of basic cereals. One tonne of rapeseed straw contains approximately $1.3 \mathrm{~kg}$ of phosphorus, 16.8 $\mathrm{kg}$ of potassium, $11.1 \mathrm{~kg}$ of calcium and $0.8 \mathrm{~kg}$ of magnesium [Szewczuk 2010].

The aim of the research was the estimation of wheat and rapeseed straw usefulness for fertilising plants in arable farming. The subject matter of the study was the analysis of the influence of soil fertilisation with wheat and rapeseed straw on yield and changes in the content of phosphorus, potassium, calcium and magnesium in winter wheat grain cultivars 'Finezja' and 'Ludwig'.

\section{MATERIALS AND METHODS}

\section{The conditions of the experiment}

The static field experiment was conducted at Agricultural Experiment Station, Grabów, Institute of Soil Science and Plant Cultivation - National Research Institute $\left(51^{\circ} 21^{\prime} \mathrm{N}\right.$, $21^{\circ} 40^{\prime} \mathrm{E}$ ) in the years 2008-2010 on Haplic Luvisol [FAO 2006]. It was based on an ongoing, since 1987, static crop rotation experiment with different variants of straw use, set up according to the randomized block method in four replications. The size of crop plots was $45 \mathrm{~m}^{2}$. In its present setup, the experiment has been conducted since the autumn of 1997 and the presented results regard $11^{\text {th }}$ $-13^{\text {th }}$ years of the experiment. The crop rotation held on all the plots were: winter rapeseed - winter wheat - winter wheat, with varying frequency of ploughing the straw. In this two factor experiment, the following factors were taken into consideration: I - winter wheat cultivars 'Finezja' and 'Ludwig', II - straw fertilisation. The experiment was conducted over the period of three years. Table 1 presents the variant number and fertilisation mode.

Rapeseed straw was applied in the amount of $3 \mathrm{t} \cdot \mathrm{ha}^{-1}$, and wheat $5 \mathrm{t} \cdot \mathrm{ha}^{-1}$ before conventional ploughing for winter cereals. Additionally, in or- der to balance $\mathrm{C}: \mathrm{N}$ proportion in ploughed straw, nitrogen in a form of ammonium nitrate was used in plots 3 and 4 in the amount of $30 \mathrm{~kg} \mathrm{~N} \cdot \mathrm{ha}^{-1}$. Winter wheat was sown in an optimal term for this region of the country in the third decade of September in the amount of 4.5 million of germinating seeds from a hectare. Wheat cultivars cultivated in the experiment were Finezja and Ludwig, both classified as quality wheat. Annual average phosphorus and potassium fertilisation in the amount of $70 \mathrm{~kg} \mathrm{P} \cdot \mathrm{ha}^{-1}$ and $120 \mathrm{~kg} \mathrm{~K} \cdot \mathrm{ha}^{-1}$ was applied in the experiment before conventional ploughing for winter cereals. Top dressing fertilisation of winter wheat with nitrogen was applied in the amount of $90 \mathrm{~kg} \mathrm{~N} \cdot \mathrm{ha}^{-1}$, yet $2 / 3$ of the dose, that is $60 \mathrm{~kg} \mathrm{~N} \cdot \mathrm{ha}^{-1}$, was applied in the early spring during the beginning of vegetation. The remaining amount $\left(30 \mathrm{~kg} \mathrm{~N} \cdot \mathrm{ha}^{-1}\right)$ was applied in the stem elongation phase (BBCH 31-32).

Plant protection against weeds and diseases was congruent with the guidelines of the Plant Protection Institute - State Research Institute in Poznań. Maxim 025 FS seed treatment in the amount of 200 and $400 \mathrm{~cm}^{3}$ of water for $100 \mathrm{~kg}$ of seed were used for seed treatment of both cultivars of winter wheat in 2008. In the following years Kinto Duo 080 FS in the amount of 200 and 400 $\mathrm{cm}^{3}$ of water were used for $100 \mathrm{~kg}$ of seed. Each autumn, winter wheat plants in the growth stage of 2-3 unfolded leaves (BBCH 12-13) were sprayed against monocot and dicot weeds. Expert Met 56 WG in the amount of $0.35 \mathrm{dm}^{3} \cdot \mathrm{ha}^{-1}$ was used in 2008, and Alister Grande 190 OD was used in the autumn of 2009 in the amount of $0.9 \mathrm{dm}^{3} \cdot \mathrm{ha}^{-1}$. In the growth stage of the first node (BBCH 31) the plants were sprayed each year against stem base diseases and powdery mildew of cereals and grasses using Alert $375 \mathrm{SC}$ in the amount of $1 \mathrm{dm}^{3} \cdot \mathrm{ha}^{-1}$. The spraying was combined with the use of growth regulator (Cycocel $460 \mathrm{SL}$ in the amount of 1.7 $\left.\mathrm{dm}^{3} \cdot \mathrm{ha}^{-1}\right)$. At the beginning of flowering (BBCH 61) the plants were protected against leaf and ear diseases of winter wheat using Charizma $207 \mathrm{EC}$ in the amount of $1.5 \mathrm{dm}^{3} \cdot \mathrm{ha}^{-1}$ in 2008 , and Artea $330 \mathrm{EC}$ in the amount of $0.5 \mathrm{dm}^{3} \cdot \mathrm{ha}^{-1}$ in 2009 and 2010. Finezja winter wheat cultivar was registered in 2002. This cultivar, originated at "Danko" Plant Breeders Ltd., and is suitable for growing all over Poland and tolerant to slightly acid soils. Ludwig winter wheat cultivar from Probstdofer Saatzucht is quality wheat (A class) with high yield potential, very high protein and gluten content and is suitable for growing all over Poland. 
Table 1. Fertilisation variant number and components used

\begin{tabular}{|c|l|}
\hline Variant & \multicolumn{1}{|c|}{ Applied fertilisation } \\
\hline 1 & Control - without ploughing the straw \\
\hline 2 & Straw ploughed one time in rotation, rapeseed only \\
\hline 3 & Straw ploughed two times in rotation - rapeseed and winter wheat straw sown after rapeseed $+30 \mathrm{~kg} \mathrm{~N} \cdot \mathrm{ha}^{-1}$ \\
\hline 4 & $\begin{array}{l}\text { Straw ploughed three times in rotation }- \text { rapeseed straw, wheat straw sown after rapeseed and wheat straw } \\
\text { sown after wheat }+30 \mathrm{~kg} \mathrm{~N} \cdot \mathrm{ha}^{-1}\end{array}$ \\
\hline 5 & $\begin{array}{l}\text { Straw ploughed three times in rotation - rapeseed straw, wheat straw sown after rapeseed and wheat straw } \\
\text { sown after wheat }\end{array}$ \\
\hline
\end{tabular}

\section{Methodology of chemical analyses}

In order to determine the total macro component content, the grain samples were mineralised in the mixture of nitric(V) acid and chloric(VII) acid in 1:1 proportion. After mineralisation of the samples the phosphorus content was determined using colimetric determination, and the contents of potassium, calcium and magnesium were determined with the use of atomic absorption spectrometer SOLAAR AA SERIES.

The analysis of the obtained results was made with the use of analysis variance. The values of LSD were calculated using Tukey's test at the statistical significance of $\alpha=0.05$. The experimental error for testing effects in experiment was means square of interaction $\mathrm{C} \times \mathrm{F} \times \mathrm{Y}$. Calculations were performed using Statistica version 10.

\section{Climatic conditions}

During the period of three years thermal conditions were highly varied: positive deviations which resulted in an increased mean annual temperature in the subsequent years $-0.9^{\circ}, 0.8^{\circ}$ and $0.4{ }^{\circ} \mathrm{C}$ respectively were predominant, in comparison with multi-year values $\left(7.9^{\circ} \mathrm{C}\right)$ - Table 2. The greatest positive deviation in air temperature was recorded in the winter and at the beginning of spring of 2007/2008 - in February the temperature exceeded the average by $4.4{ }^{\circ} \mathrm{C}$. In the period 2008/2009 nearly all months were warmer, with the greatest deviation $\left(2.6{ }^{\circ} \mathrm{C}\right)$ recorded in April. The period 2009/2010 was characterised by low temperatures in winter, it was particularly chilly in January as the mean air temperature was below the average by $5.9^{\circ} \mathrm{C}$.

Table 2. Deviation of the multiannual values (1976-2010) of air temperature and total precipitation according to months and seasons in the period of 2007/2008 and 2009/2010

\begin{tabular}{|l|c|c|c|c|c|c|c|c|}
\hline \multicolumn{1}{|c|}{ Deviation of the norm } & Years & 09 & 10 & 11 & 12 & 01 & 02 & $09-08$ \\
\hline \multirow{3}{*}{ Air temperature, ${ }^{\circ} \mathrm{C}$} & $2007 / 2008$ & -0.2 & -0.6 & -1.8 & 0.3 & 3.5 & 4.4 & 0.9 \\
& $2008 / 2009$ & -0.5 & 1.5 & 1.9 & 2.2 & -0.5 & 0.6 & 0.8 \\
& $2009 / 2010$ & 1.9 & -1.3 & 2.3 & -0.3 & -5.9 & -0.4 & 0.4 \\
\hline Norm, ${ }^{\circ} \mathrm{C}$ & $\mathbf{1 9 7 6 - 2 0 1 0}$ & $\mathbf{1 3 . 0}$ & $\mathbf{8 . 2}$ & $\mathbf{3 . 0}$ & $\mathbf{- 1 . 0}$ & $\mathbf{- 2 . 7}$ & $\mathbf{- 1 . 8}$ & $\mathbf{7 . 9}$ \\
\hline & $2007 / 2008$ & 119 & 30 & 117 & 28 & 164 & 64 & 99 \\
Precipitation totals, \% & $2008 / 2009$ & 109 & 126 & 92 & 121 & 75 & 113 & 111 \\
& $2009 / 2010$ & 50 & 21 & 173 & 146 & 70 & 100 & 113 \\
\hline Norm, mm & $\mathbf{1 9 7 6 - 2 0 1 0}$ & $\mathbf{6 4 . 9}$ & $\mathbf{4 2 . 9}$ & $\mathbf{4 1 . 7}$ & $\mathbf{3 7 . 6}$ & $\mathbf{3 1 . 6}$ & $\mathbf{2 6 . 4}$ & $\mathbf{6 3 7 . 4}$ \\
\hline
\end{tabular}

\begin{tabular}{|l|c|c|c|c|c|c|c|c|}
\hline \multicolumn{1}{|c|}{ Deviation of the norm } & Years & 03 & 04 & 05 & 06 & 07 & 08 & $09-08$ \\
\hline \multirow{3}{*}{ Air temperature, ${ }^{\circ} \mathrm{C}$} & $2007 / 2008$ & 1.4 & 0.9 & -0.6 & 1.0 & 0.4 & 1.1 & 0.9 \\
& $2008 / 2009$ & 0.1 & 2.6 & -0.2 & -0.2 & 1.2 & 0.3 & 0.8 \\
& $2009 / 2010$ & 0.9 & 0.9 & 0.2 & 1.0 & 3.0 & 2.1 & 0.4 \\
\hline Norm, ${ }^{\circ} \mathrm{C}$ & $\mathbf{1 9 7 6 - 2 0 1 0}$ & $\mathbf{2 . 1}$ & $\mathbf{8 . 1}$ & $\mathbf{1 3 . 7}$ & $\mathbf{1 6 . 6}$ & $\mathbf{1 8 . 5}$ & $\mathbf{1 7 . 8}$ & $\mathbf{7 . 9}$ \\
\hline & $2007 / 2008$ & 161 & 160 & 140 & 65 & 99 & 67 & 99 \\
Precipitation totals, \% & $2008 / 2009$ & 197 & 1 & 92 & 150 & 140 & 92 & 111 \\
& $2009 / 2010$ & 65 & 46 & 182 & 64 & 62 & 191 & 113 \\
\hline Norm, mm & $\mathbf{1 9 7 6 - 2 0 1 0}$ & $\mathbf{3 9 . 0}$ & $\mathbf{4 4 . 8}$ & $\mathbf{6 2 . 6}$ & $\mathbf{7 8 . 8}$ & $\mathbf{8 6 . 0}$ & $\mathbf{8 1 . 1}$ & $\mathbf{6 3 7 . 4}$ \\
\hline
\end{tabular}


The other months were warmer with the greatest positive deviation $\left(3.0^{\circ} \mathrm{C}\right)$ recorded in July.

Annual precipitation was within average during the period 2007/2008 and in the remaining two periods it was slightly above the average value (Table 3 ). Humidity conditions were more varied in individual months, especially in the year 2009 - in March precipitation amounted to $200 \%$ of the average values, and in April only $1 \%$. The characteristics of the humidity conditions [Michalska and Kalbarczyk 2005] in the two-months-long periods from March to August is given in Table 3 .

The spring of 2008 is regarded as moist, even extremely moist at its beginning, while the remaining periods were within the average. The vegetation season of 2009 was characterised by interchangeable dry and moist periods, and the beginning of spring of 2010 (03-04) as well as the beginning of summer (06-07) were dry - the remaining twomonth-long periods were within average.

\section{RESULTS AND DISCUSSION}

\section{Grain yield}

The yield was the greatest in the first year of the experiment during which the most favourable weather-conditions occurred. The dependence of the yield on the meteorological conditions is confirmed by the numerous publications [Gaj 2012; Järvan et al. 2011; Joniec 2011; Masilionytė \& Maikštėnienè 2011]. In the two subsequent years, the grain yield was lower than in the first year of the experiment. Therefore, it is most valid to analyse the mean results from the three-year experiment. Taking into consideration the mean yield values from the period of three years, the grain yield of wheat cultivar Ludwig was higher by $0.7 \mathrm{t} \cdot \mathrm{ha}^{-1}$. Variations in the fertilisation variants had little effect on wheat grain yield and according to the calculations the effect was not significant. There were differences in the reaction of the cultivars. The yield of

Table 3. Estimation humidity conditions in the two-month periods, spring and summer

\begin{tabular}{|c|c|c|c|c|c|}
\hline Years-months & 03-04 & $04-05$ & $05-06$ & $06-07$ & $07-08$ \\
\hline 2008 & very moist & moist & normal & normal & normal \\
\hline 2009 & normal & dry & normal & wet & normal \\
\hline 2010 & dry & normal & normal & dry & normal \\
\hline
\end{tabular}

Table 4. Winter wheat grain yield $\left(\mathrm{t} \cdot \mathrm{ha}^{-1}\right)$ depending on cultivar $(\mathrm{C})$, fertilization $(\mathrm{F})$ variant and years $(\mathrm{Y})$

\begin{tabular}{|c|c|c|c|c|c|}
\hline \multirow{2}{*}{ Cultivar } & \multirow{2}{*}{ Fertilization variant } & \multicolumn{3}{|c|}{ Years } & \multirow{2}{*}{ Average } \\
\hline & & 2008 & 2009 & 2010 & \\
\hline \multirow{5}{*}{ Finezja } & 1 & 6.36 & 5.92 & 5.84 & 6.04 \\
\hline & 2 & 6.52 & 5.98 & 5.84 & 6.11 \\
\hline & 3 & 6.42 & 5.90 & 5.88 & 6.07 \\
\hline & 4 & 6.43 & 6.16 & 5.74 & 6.11 \\
\hline & 5 & 6.74 & 5.96 & 5.87 & 6.19 \\
\hline \multicolumn{2}{|l|}{ Average } & 6.48 & 5.98 & 5.83 & 6.10 \\
\hline \multirow{5}{*}{ Ludwig } & 1 & 7.30 & 7.10 & 6.08 & 6.83 \\
\hline & 2 & 7.34 & 6.57 & 5.98 & 6.63 \\
\hline & 3 & 7.33 & 6.86 & 6.28 & 6.82 \\
\hline & 4 & 7.04 & 7.51 & 6.24 & 6.93 \\
\hline & 5 & 7.12 & 6.62 & 6.12 & 6.62 \\
\hline \multicolumn{2}{|l|}{ Average } & 7.22 & 6.93 & 6.14 & 6.77 \\
\hline \multirow{5}{*}{ Average } & 1 & 6.83 & 6.51 & 5.96 & 6.43 \\
\hline & 2 & 6.93 & 6.27 & 5.91 & 6.37 \\
\hline & 3 & 6.87 & 6.38 & 6.08 & 6.44 \\
\hline & 4 & 6.74 & 6.83 & 5.99 & 6.52 \\
\hline & 5 & 6.93 & 6.29 & 5.99 & 6.40 \\
\hline \multicolumn{2}{|l|}{ Total average } & 6.85 & 6.46 & 5.99 & 6.43 \\
\hline \multicolumn{2}{|l|}{ LSD $_{0.05}$ for: } & \multicolumn{4}{|c|}{$C-0.117, F-$ n.s., $Y-0.178, C \times F-$ n.s., $C \times Y-0.252, F \times Y-$ n.s. } \\
\hline
\end{tabular}


winter wheat cultivar 'Finezja' was similar regardless of the fertilisation variant. The analysis of mean values of wheat cultivar Ludwig shows that straw fertilisation caused a slight decrease in yield. Higher yield achieved using additional nitrogen fertilisation can be attributed to the fact that, according to other authors [Buraczyńska and Ceglarek 2011b; Wysokiński and Kalembasa, 2011; Czyżyk and Rajmund. 2013; Janušauskaite et al. 2013], straw fertilisation causes an unfavourable phenomenon of phosphorus regression in soil which results in the decrease in yield, which can be compensated by introducing complementary doses of nitrogen (Table 4).

\section{Phosphorus (P)}

Phosphorus is a macrocomponent which as a non-metal makes up organic compounds (phytins, phospholipids and nucleic acids) found in wheat grain. The average phosphorus content in wheat grain is approximately $4 \mathrm{~g}$ $\mathrm{P} \cdot \mathrm{kg}^{-1} \mathrm{~d}$.m. The amount of phosphorus in wheat grain cultivar Finezja ranged from 3.36 to 4.27 $\mathrm{g} \cdot \mathrm{kg}^{-1} \mathrm{~d}$.m. The phosphorus content in wheat grain cultivar Ludwig ranged from 4.01 to 4.80 $\mathrm{g} \cdot \mathrm{kg}^{-1}$ d.m. (Table 5). The phosphorus content in wheat grain cultivars 'Finezja' and 'Ludwig' was not significantly influenced by organic fertilization with straw or by complementary fertilization with nitrogen, which has been proved in numerous studies on the topic [Wacławowicz et.al. 2005; Wiśniowska-Kielian and Klima 2006; Wilczewski and Skinder 2011].

\section{Potassium (K)}

Potassium is found in plants as potassium ions (I). Contrary to phosphorus it does not form organic compounds, yet it plays a fundamental part in many biochemical and physiological processes such as, among others, the transport of organic and inorganic compounds in vascular plant tissue. The average potassium content in winter wheat grain is $3.5 \mathrm{~g} \cdot \mathrm{kg}^{-1} \mathrm{~d} . \mathrm{m}$. [Bobrecka-Jamro et al. 2013]. The amount of potassium in wheat grain cultivar 'Finezja' ranged from 2.76 to 3.88 $\mathrm{g} \cdot \mathrm{kg}^{-1}$ d.m., and in cultivar Ludwig the amount of potassium was similar and ranged from 2.96 to $3.89 \mathrm{~g} \cdot \mathrm{kg}^{-1} \mathrm{~d}$.m. (Table 6). The comparison of grain richness in individual years shows that the content of potassium was the highest in the second year of the experiment. Precipitation in June and July of that year exceeded manifold the mean

Table 5. Phosphorus content in wheat grain ( $\mathrm{g} \mathrm{P} \cdot \mathrm{kg}^{-1} \mathrm{~d}$.m.) depending on cultivar $(\mathrm{C})$, fertilization $(\mathrm{F})$ variant and years $(\mathrm{Y})$

\begin{tabular}{|c|c|c|c|c|c|}
\hline \multirow{2}{*}{ Cultivar } & \multirow{2}{*}{ Fertilization variant } & \multicolumn{3}{|c|}{ Years } & \multirow{2}{*}{ Average } \\
\hline & & 2008 & 2009 & 2010 & \\
\hline \multirow{5}{*}{ Finezja } & 1 & 4.01 & 4.27 & 3.75 & 4.01 \\
\hline & 2 & 4.10 & 4.01 & 4.27 & 4.10 \\
\hline & 3 & 3.36 & 4.01 & 4.01 & 3.80 \\
\hline & 4 & 4.01 & 4.27 & 4.10 & 4.13 \\
\hline & 5 & 3.75 & 4.10 & 4.01 & 3.95 \\
\hline \multicolumn{2}{|l|}{ Average } & 3.89 & 4.13 & 4.03 & 4.00 \\
\hline \multirow{5}{*}{ Ludwig } & 1 & 4.01 & 4.27 & 4.10 & 4.13 \\
\hline & 2 & 4.10 & 4.10 & 4.53 & 4.24 \\
\hline & 3 & 4.27 & 4.10 & 4.53 & 4.30 \\
\hline & 4 & 4.10 & 4.27 & 4.80 & 4.39 \\
\hline & 5 & 4.27 & 4.27 & 4.53 & 4.36 \\
\hline \multicolumn{2}{|l|}{ Average } & 4.15 & 4.20 & 4.50 & 4.28 \\
\hline \multirow{5}{*}{ Average } & 1 & 4.01 & 4.27 & 3.92 & 4.07 \\
\hline & 2 & 4.05 & 4.05 & 4.40 & 4.17 \\
\hline & 3 & 3.81 & 4.05 & 4.27 & 4.06 \\
\hline & 4 & 4.05 & 4.27 & 4.45 & 4.26 \\
\hline & 5 & 4.01 & 4.18 & 4.27 & 4.15 \\
\hline \multicolumn{2}{|l|}{ Total average } & 3,99 & 4.17 & 4.26 & 4.14 \\
\hline \multicolumn{2}{|l|}{$\mathrm{LSD}_{0.05}$ for: } & \multicolumn{4}{|c|}{$C-0.133, F-$ n.s., $Y-0.202, C \times F, C \times Y$ and $F \times Y-$ n.s. } \\
\hline
\end{tabular}


Table 6. Potassium content in wheat grain $\left(\mathrm{g} \mathrm{K} \cdot \mathrm{kg}^{-1} \mathrm{~d} . \mathrm{m}\right.$.) depending on cultivar (C), fertilisation (F) variant and years (Y)

\begin{tabular}{|c|c|c|c|c|c|}
\hline \multirow{2}{*}{ Cultivar } & \multirow{2}{*}{ Fertilization variant } & \multicolumn{3}{|c|}{ Years } & \multirow{2}{*}{ Average } \\
\hline & & 2008 & 2009 & 2010 & \\
\hline \multirow{5}{*}{ Finezja } & 1 & 3.13 & 3.87 & 3.27 & 3.42 \\
\hline & 2 & 2.96 & 3.75 & 3.20 & 3.30 \\
\hline & 3 & 2.81 & 3.63 & 3.23 & 3.22 \\
\hline & 4 & 3.15 & 3.88 & 3.47 & 3.50 \\
\hline & 5 & 2.76 & 3.58 & 3.03 & 3.12 \\
\hline \multicolumn{2}{|l|}{ Average } & 2.96 & 3.74 & 3.24 & 3.31 \\
\hline \multirow{5}{*}{ Ludwig } & 1 & 2.96 & 3.81 & 3.27 & 3.35 \\
\hline & 2 & 3.32 & 3.86 & 3.20 & 3.46 \\
\hline & 3 & 3.15 & 3.59 & 3.23 & 3.32 \\
\hline & 4 & 3.18 & 3.89 & 3.47 & 3.51 \\
\hline & 5 & 3.05 & 3.89 & 3.03 & 3.32 \\
\hline \multicolumn{2}{|l|}{ Average } & 3.13 & 3.81 & 3.24 & 3.39 \\
\hline \multirow{5}{*}{ Average } & 1 & 3.04 & 3.84 & 3.27 & 3.38 \\
\hline & 2 & 3.14 & 3.80 & 3.20 & 3.38 \\
\hline & 3 & 2.98 & 3.61 & 3.23 & 3.27 \\
\hline & 4 & 3.16 & 3.88 & 3.47 & 3.50 \\
\hline & 5 & 2.90 & 3.73 & 3.03 & 3.22 \\
\hline \multicolumn{2}{|l|}{ Total average } & 3.05 & 3.77 & 3.24 & 3.35 \\
\hline \multicolumn{2}{|l|}{ LSD $_{0.05}$ for: } & \multicolumn{4}{|c|}{$C-$ n.s.; $F-0.198 ; Y-0.127, C \times F, C \times Y$ and $F \times Y-n . s$} \\
\hline
\end{tabular}

precipitation values from long-term period. This could foster an increased dissolution of potassium compounds and therefore its greater accessibility for the cultivated wheat. Although wheat and rapeseed straw contain several times more potassium, the definite influence of straw fertilisation on potassium content in wheat cultivar Finezja and Ludwig was not reported in the experiment. The stability of potassium content in wheat grain depending on organic and mineral fertilisation is ascertained in many studies on the topic [Wacławowicz et al. 2005; Wiśniowska-Kielian and Klima, 2006; Rachoń and Szumiło, 2009; Wilczewski and Skinder, 2011].

\section{Calcium (Ca)}

Calcium, as a basic macro component for plants. It regulates the activity of many enzymes; influences plant cell division, growth and proper functioning of chloroplasts, mitochondria and chromosomes. It also plays a part in water management of plants and maintenance of mono- and divalent cation balance. The content of calcium in wheat grain is relatively diversified. On the basis of the comparison of the content of macro components in wheat grain from organic and conventional faming in Małopolska Voivodeship,
[Wiśniowska-Kielan and Klima 2006] state that wheat grain contains $0.40 \mathrm{~g} \cdot \mathrm{kg}^{-1}$. In the study by Brzozowska [2008] macroelement content in winter wheat grain is affected by cultivation and nitrogen application that calcium content in dry matter of wheat grain ranges from 0.29 to 0.70 $\mathrm{g} \cdot \mathrm{kg}^{-1} \mathrm{~d} . \mathrm{m}$. The content of calcium in wheat grain cultivars 'Finezja' and 'Ludwig' was similar and ranged from 0.45 to $0.99 \mathrm{~g} \cdot \mathrm{kg}^{-1}$ d.m. (Table 7). The experiment did not show a significant influence of straw fertilization on calcium content in wheat grain cultivars 'Finezja' and 'Ludwig'. The explanation of this fact could be that wheat and rapeseed straw are characterised by a similar content of calcium.

\section{Magnesium (Mg)}

Magnesium is an indispensable element of chlorophyll and plays a role in various physiological processes such as photosynthesis, metabolism of carbohydrates, proteins and lipids [Bose et al. 2010; Hao and Papadopoulos 2004]. Magnesium deficiency causes, above all, a decrease in yield. As compared to other plants, cereals accumulate moderate amounts of magnesium. The average magnesium content in wheat grain is approximately $0.8 \mathrm{~g} \mathrm{Mg} \cdot \mathrm{kg}^{-1} \mathrm{~d}$.m. [Wiśniowska- 
Table 7. Calcium content in wheat grain $\left(\mathrm{g} \mathrm{Ca} \cdot \mathrm{kg}^{-1} \mathrm{~d} . \mathrm{m}\right.$.) depending on cultivar $(\mathrm{C})$, fertilisation $(\mathrm{F})$ variant and years $(\mathrm{Y})$

\begin{tabular}{|c|c|c|c|c|c|}
\hline \multirow{2}{*}{ Cultivar } & \multirow{2}{*}{ Fertilization variant } & \multicolumn{3}{|c|}{ Years } & \multirow{2}{*}{ Average } \\
\hline & & 2008 & 2009 & 2010 & \\
\hline \multirow{5}{*}{ Finezja } & 1 & 0.45 & 0.51 & 0.53 & 0.50 \\
\hline & 2 & 0.59 & 0.46 & 0.71 & 0.59 \\
\hline & 3 & 0.41 & 0.55 & 0.55 & 0.50 \\
\hline & 4 & 0.56 & 0.99 & 0.52 & 0.69 \\
\hline & 5 & 0.60 & 0.71 & 0.57 & 0.63 \\
\hline \multicolumn{2}{|l|}{ Average } & 0.52 & 0.64 & 0.58 & 0.58 \\
\hline \multirow{5}{*}{ Ludwig } & 1 & 0.77 & 0.77 & 0.57 & 0.70 \\
\hline & 2 & 0.56 & 0.66 & 0.48 & 0.57 \\
\hline & 3 & 0.47 & 0.66 & 0.66 & 0.60 \\
\hline & 4 & 0.75 & 0.50 & 0.49 & 0.50 \\
\hline & 5 & 0.53 & 0.55 & 0.53 & 0.54 \\
\hline \multicolumn{2}{|l|}{ Average } & 0.62 & 0.63 & 0.55 & 0.60 \\
\hline \multirow{5}{*}{ Average } & 1 & 0.61 & 0.64 & 0.55 & 0.60 \\
\hline & 2 & 0.57 & 0.56 & 0.59 & 0.58 \\
\hline & 3 & 0.44 & 0.60 & 0.60 & 0.55 \\
\hline & 4 & 0.65 & 0.74 & 0.50 & 0.63 \\
\hline & 5 & 0.56 & 0.63 & 0.55 & 0.58 \\
\hline \multicolumn{2}{|l|}{ Total average } & 0.70 & 0.64 & 0.56 & 0.59 \\
\hline \multicolumn{2}{|l|}{$\operatorname{LSD}_{0.05}$ for: } & \multicolumn{4}{|c|}{$\mathrm{C} \times \mathrm{F}, \mathrm{C} \times \mathrm{Y}$ and $\mathrm{F} \times \mathrm{Y}-$ n.s. $\mathrm{C} \times \mathrm{F}, \mathrm{C} \times \mathrm{Y}$ and $\mathrm{F} \times \mathrm{Y}-$ n.s. } \\
\hline
\end{tabular}

Table 8. Magnesium content in wheat grain ( $\mathrm{g} \mathrm{Mg} \cdot \mathrm{kg}^{-1} \mathrm{~d} . \mathrm{m}$.) depending on cultivar (C), fertilisation (F) variant and years $(\mathrm{Y})$

\begin{tabular}{|c|c|c|c|c|c|}
\hline \multirow{2}{*}{ Cultivar } & \multirow{2}{*}{ Fertilization variant } & \multicolumn{3}{|c|}{ Years } & \multirow{2}{*}{ Average } \\
\hline & & 2008 & 2009 & 2010 & \\
\hline \multirow{5}{*}{ Finezja } & 1 & 0.94 & 0.86 & 0.85 & 0.88 \\
\hline & 2 & 0.91 & 0.82 & 0.84 & 0.87 \\
\hline & 3 & 0.91 & 0.83 & 0.88 & 0.87 \\
\hline & 4 & 0.95 & 0.98 & 0.77 & 0.90 \\
\hline & 5 & 0.90 & 0.82 & 0.84 & 0.85 \\
\hline \multicolumn{2}{|l|}{ Average } & 0.92 & 0.86 & 0.84 & 0.87 \\
\hline \multirow{5}{*}{ Ludwig } & 1 & 1.06 & 1.02 & 0.92 & 1.00 \\
\hline & 2 & 1.03 & 0.97 & 0.99 & 1.00 \\
\hline & 3 & 1.06 & 0.87 & 0.97 & 0.97 \\
\hline & 4 & 1.09 & 0.91 & 1.01 & 1.00 \\
\hline & 5 & 1.01 & 0.94 & 0.88 & 0.94 \\
\hline \multicolumn{2}{|l|}{ Average } & 1.05 & 0.94 & 0.95 & 0.98 \\
\hline \multirow{5}{*}{ Average } & 1 & 1.00 & 0.94 & 0.88 & 0.94 \\
\hline & 2 & 0.97 & 0.89 & 0.91 & 0.95 \\
\hline & 3 & 0.98 & 0.85 & 0.92 & 0.92 \\
\hline & 4 & 1.02 & 0.94 & 0.89 & 0.95 \\
\hline & 5 & 0.95 & 0.88 & 0.86 & 0.90 \\
\hline \multicolumn{2}{|l|}{ Total average } & 0.99 & 0.90 & 0.89 & 0.93 \\
\hline \multicolumn{2}{|l|}{ LSD $_{0.05}$ for: } & \multicolumn{4}{|c|}{$\mathrm{C}-0.051, \mathrm{~F}-$ n.s., $\mathrm{Y}-0.077, \mathrm{C} \times \mathrm{F}, \mathrm{C} \times \mathrm{Y}$ and $\mathrm{F} \times \mathrm{Y}-$ n.s. } \\
\hline
\end{tabular}


Kielan and Klima 2006]. Magnesium content in wheat grain cultivar Finezja ranged from 0.77 to $0.98 \mathrm{~g} \cdot \mathrm{kg}^{-1} \mathrm{~d}$.m. Wheat grain cultivar Ludwig contained greater amounts of magnesium which ranged from 0.87 to $1.09 \mathrm{~g} \cdot \mathrm{kg}^{-1} \mathrm{~d} . \mathrm{m}$. (Table 8). The comparison of wheat grain content in individual years of the experiment shows that the highest content of magnesium was recorded in the first year of the experiment. In the subsequent years the magnesium content gradually decreased in wheat grain of both cultivars. Wheat and rapeseed fertilisation used in the experiment did not influence any changes in magnesium content of winter wheat grain (Table 8). The lack of diversity in magnesium content in wheat grain could result from similar magnesium content in straw. In their analyses many authors support the findings which indicate the lack of significant differences in magnesium content in wheat grain as a result of diversified fertilisation [Wiśniowska-Kielian and Klima, 2006; Kraska and Pałys, 2009; Gondek and Gondek 2010; Wilczewski and Skinder 2011].

The mean content of phosphorus, potassium, calcium and magnesium in wheat grain cultivar Finezja and Ludwig cultivated in the experiment amounted to: $4.14,3.35,0.93$ and $0.59 \mathrm{~kg}^{-1}$ of dry matter respectively, and did not differ significantly from the results of other research studies. Comparing the content of the macro components in question in wheat grain, the following disparity can be deduced: $\mathrm{P}>\mathrm{K}>\mathrm{Mg}>\mathrm{Ca}$. WiśniowskaKielian and Klima [2006] report the same relationship in their comparison of the content of macro components in wheat grain from organic and conventional farming.

\section{CONCLUSIONS}

1. The effect of fertilisation with wheat and rapeseed straw did not have a significant effect on grain yield of winter wheat cultivars 'Finezja' and 'Ludwig'.

2. The introduction of complementary nitrogen fertilisation caused an increase in grain yield of wheat cultivar 'Ludwig'.

3. Organic fertilisation with wheat and rapeseed straw as well as complementary nitrogen fertilisation did not significantly differentiate the content of phosphorus, potassium, calcium and magnesium in winter wheat grain cultivars 'Finezja' and 'Ludwig'.

\section{REFERENCES}

1. Bobrecka-Jamro D., Kruczek G., Romaniak M., Jarecki W., Buczek J. 2013. Effect of the dose and method of top-dressing with nitrogen on the yield and quality of winter wheat grain. Acta Scientiarum Polonorum, Agricultura, 12 (4), 19-30.

2. Bose J., Babourina O., Rengel Z. 2010. Role of magnesium in alleviation of aluminium toxicity in plants. Journal of Experimental Botany, 62 (7), 2251-2264.

3. Brzozowska I. 2008. Macroelement content in winter wheat grain as affected by cultivation and nitrogen application methods. Acta Agrophysica, 11 (1), 23-32.

4. Buraczyńska D., Ceglarek F. 2011a. previous crop value of post-harvest residues and straw of spring wheat, field pea and their mixtures for winter triticale part i. weight and chemical composition of post-harvest residues and straw. Acta Scientiarum Polonorum, Agricultura, 10 (2), 3-18.

5. Buraczyńska D., Ceglarek F. 2011b. Previous crop value of post-harvest residues and straw of spring wheat, field pea and their mixtures for winter triticale. Part II. Winter triticale yield. Acta Scientiarum Polonorum, Agricultura, 10 (2), 19-32.

6. Czyżyk F., Rajmund A. 2013. Przenikanie azotu do środowiska wodnego wskutek nawożenia gleby lekkiej. Inżynieria Ekologiczna, 29-34.

7. Dz.U.02.165.1359. 2002. Rozporządzenie Ministra Środowiska z dnia 9 września 2002 r. w sprawie standardów jakości gleby oraz standardów jakości ziemi [Regulation of the Minister of Environment dated 9 September 2002 on soil quality standards and land quality standards]. (Dz. U. z dnia 4 października 2002 r.) (in Polish).

8. Dz.U.2011.86.476. 2011. Rozporządzenie Ministra Środowiska z dnia 5 kwietnia 2011 r. w sprawie procesu odzysku R10. [The regulation of the Minister of Environment on R10 recovery operation] (Dz. U. z dnia 22 kwietnia 2011 r.) (in Polish).

9. FAO. 2006. Guidelines for soil description. Food and Agriculture Organization of the United Nations, 1-97 (4 $4^{\text {th }}$ ed.).

10. Gaj R. 2012. The effect of different phosphorus and potassium fertilization on plant nutrition in critical stage and yield of winter triticale. Journal of Central European Agriculture, 13 (4), 704-716.

11. Gondek K., Gondek A. 2010. Wpływ nawożenia mineralnego na plonowanie i zawartość wybranych makro i mikroelementów w pszenicy jarej. [The influence of mineral fertilization on the yield and content of selected macro and microelements in spring wheat]. Journal of Research and Applications in Agricultural Engineering, 55 (1), 30-36 (in Polish). 
12. Janušauskaitė D., Arlauskienė A., Maikštėnienė S. 2013. Soil mineral nitrogen and microbial parameters as influenced by catch crops and straw management. Zemdirbyste-Agriculture, 100 (1), 9-18.

13. Järvan M., Edesi L., Adamson A. 2012. Effect of sulphur fertilization on grain yield and yield components of winter wheat. Acta Agriculturae Scandinavica, Section B - Soil \& Plant Science, 62 (5), 401-409.

14. Joniec A. 2011. Plonowanie pszenicy ozimej w zależności od systemu uprawy roli. [Effect of the tillage and reduced system on the yield of winter wheat]. EPISTEME, 12 (I), 161-167 (in Polish).

15. Hao X., Papadopoulos A.P. 2004. Effects of Calcium and Magnesium on Plant Growth, Biomass Partitioning, and Fruit Yield of Winter Greenhouse Tomato. HORTSCIENCE, 39 (3), 512-515.

16. Masilionytė L, Maikštenienè S. 2011. The effect of agronomic and meteorological factors on the yield of main and catch crops. Zemdirbyste-Agriculture, 98 (3), 235-244.

17. Michalska B, Kalbarczyk E. 2005. Longterm changes in air temperature and precipitation on Szczecińska Lowland. EJPAU Ser. Environmental Development, vol. 8, iss. 1 (www.media.ejpau.pl).

18. Ministry of agriculture and rural development. 2010. Wytyczne w zakresie wykorzystania produktów ubocznych oraz zalecanego postępowania $\mathrm{z}$ odpadami $\mathrm{w}$ rolnictwie i przemyśle rolno-spożywczym. [Guidelines for the use of by-products and recommended behavior of waste in agriculture and agri-food industry] (in Polish).
19. Rachoń L. Szumiło G. 2009. Comparison of chemical composition of selected winter wheat species. Journal of Elementology, 14 (1), 135-146.

20. Szewczuk Cz. 2010. Zanim sprzedasz słomę - bilans substancji odżywczych. [Before the sale of straw - the balance of nutrients]. Wiadomości Rolnicze Polska, 1, 1-3 (in Polish).

21. Wacławowicz R., Parylak D. Śniady R. 2005. Następczy wpływ nawożenia organicznego oraz mineralnego azotowego na plonowanie oraz wybrane cechy jakościowe ziarna pszenicy jarej. [Residual effect of organic and nitrogen fertilization on the yields and selected quality features of spring wheat grain]. Pamiętnik. Puławski, 139, 277-288 (in Polish).

22. Wilczewski E., Skinder Z. 2011. Wartość przedplonowa roślin niemotylkowatych uprawianych w międzyplonie ścierniskowym dla pszenicy jarej cz. II. Zawartość ważniejszych makroskładników w ziarnie i słomie. [Previous crop value of non-legumes grown in stubble catch crop for spring wheat part II. content of major macronutrients in grain and straw]. Fragmenta Agronomica, 28 (1), 107-114 (in Polish).

23. Wiśniowska-Kielian B., Klima K. 2006. Comparison of macroelement contents in the winter wheat grain from organic and conventional farms, Journal of Research and Applications in Agricultural Engineering, 51 (2), 204-208.

24. Wysokiński A., Kalembasa S. 2011. The Yield and Utilization Coefficient of Nitrogen by Plants after Applying of Fresh and Composted Sewage Sludge with Mineral and Organic Additions. Polish Journal of Environmental Studies. 20 (6), 1617-1625. 